\title{
Congenital Primary Milium on Nipple in a 3 Month Old Female Infant
}

\section{Anup Kumar Tiwary ${ }^{*}$}

Department of Dermatology, Venereology and Leprosy, Government Medical College, Haldwani, Uttarakhand, India

${ }^{*}$ Corresponding author: Anup Kumar Tiwary, Assistant Professor, Department of Dermatology, Venereology and Leprosy, House No. 12, Diamond Building, Government Medical College, Haldwani, Uttarakhand, India, Tel: +918809085872; E-mail: anup07tunnu07@gmail.com

Received date: April 27, 2017; Accepted date: April 30, 2017; Published date: May 08, 2017

Copyright: $\odot 2017$ Tiwary AK. This is an open-access article distributed under the terms of the Creative Commons Attribution License, which permits unrestricted use, distribution, and reproduction in any medium, provided the original author and source are credited.

Citation: Tiwary AK (2017) Congenital Primary Milium on Nipple in a 3 Month Old Female Infant. J Pigment Disord 4: e110. doi:10.4172/2376-0427.1000e110

\section{Congenital Primary Milium on Nipple}

\section{Introduction}

Milia are quite common benign keratin cysts. Its distribution and course depends upon whether it is primary or secondary in origin. The characteristic clinical presentation usually makes the diagnosis but on rare instances, histopathologic confirmation is warranted if primary milium is located on atypical sites. Here we report a case of congenital primary milium of nipple in a 3 month old female infant.

A 3 month old female infant presented with a solitary, non-tender, firm, pearly white, domed growing cystic lesion of size around $3 \mathrm{~mm}$ in diameter on her left nipple, being present since birth (Figure 1a). There were no associated symptoms, nipple discharge or underlying mass in the breast tissue of either side. For diagnostic and therapeutic purpose, lesion was excised and sent for histopathologic examination which revealed a cyst lined with stratified squamous epithelium filled with lamellated keratins in the lumen (Figure 1b). Based on the clinicopathologic correlations, this case was diagnosed as congenital primary milium of nipple.

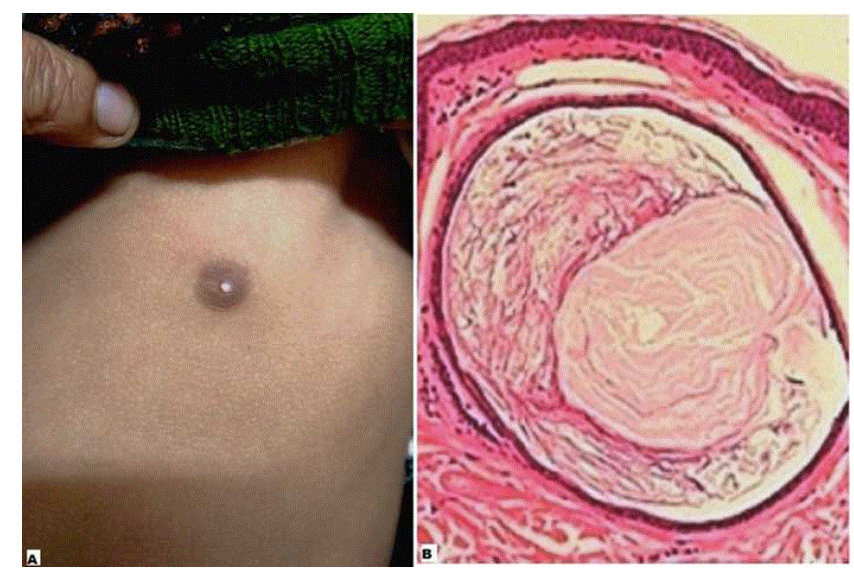

Figure 1: a) Solitary, pearly white, domed cystic lesion of size around $3 \mathrm{~mm}$ in diameter on left nipple b) sub epidermal cyst lined by stratified squamous epithelium filled with lamellated keratins in the lumen $(\mathrm{H} \& \mathrm{E}, \mathrm{X} 400)$.
Milia are tiny sub epidermal keratin cysts of usually 1-2 $\mathrm{mm}$ in diameter, contains lamellated keratins and present as pearly white or whitish-yellow domed papules [1]. Milia may be primary, probably resulting from the embryonic abnormality in the epithelial bud, or secondary originating from the damaged eccrine ducts or pilosebaceous units [2]. Onset of primary milia may be congenital or after birth. These appear spontaneously and of note, spontaneous resolution of congenital forms may also occur mostly during the fourth week of life [2]. Congenital primary milia are seen to occur in up to $50 \%$ of full-term neonates, predominantly affecting nose, infraorbital and periocular skin [3]. Uncommonly, solitary larger milium may occur on the penis, scrotum, areola and vulva $[2,3]$.

Of note, we were able to find only 4 previous cases of 'primary milium on nipple in infant' and only 2 of them were congenital in onset (our case is third) [3].

Differential diagnosis includes milia-like idiopathic calcinosis cutis, syringomas with milia- like structures, trichoepitheliomas, comedonal acne and neonatal fibroadnexal polyp and military osteoma.[3,4] Characteristic morphology and lamellated accumulation of keratins within cystic lumen on biopsy rule out all the above mentioned conditions $[3,4]$.

Considering the possibility of spontaneous resolution, surgical intervention can be delayed in the absence of any complications such as bleeding on recurrent trauma or secondary infection. To prevent such complications, complete excision or incision followed by manual expression of the contents should be done [3].

\section{References}

1. Spyropoulou GA, Pavlidis L, Trakatelli M (2015) Rare benign tumours of the nipple. J Eur Acad Dermatol Venereol 29: 7-13.

2. Park J, Kim JI, Kim DW (2014) Congenital primary milium of the nipple. Dermatolog Sinica 32: 129-130.

3. Ferreira MG, Salgado MB (2017) Congenital Milium of the Nipple. Pediatr Dermatol 34:e28-e29.

4. Jain S, Sarkar R, Garg VK (2012) Epidermal inclusion cyst or giant milium of the nipple. Indian J Dermatol Venereol Leprol 78: 103-105. 